Provided for non-commercial research and education use. Not for reproduction, distribution or commercial use.

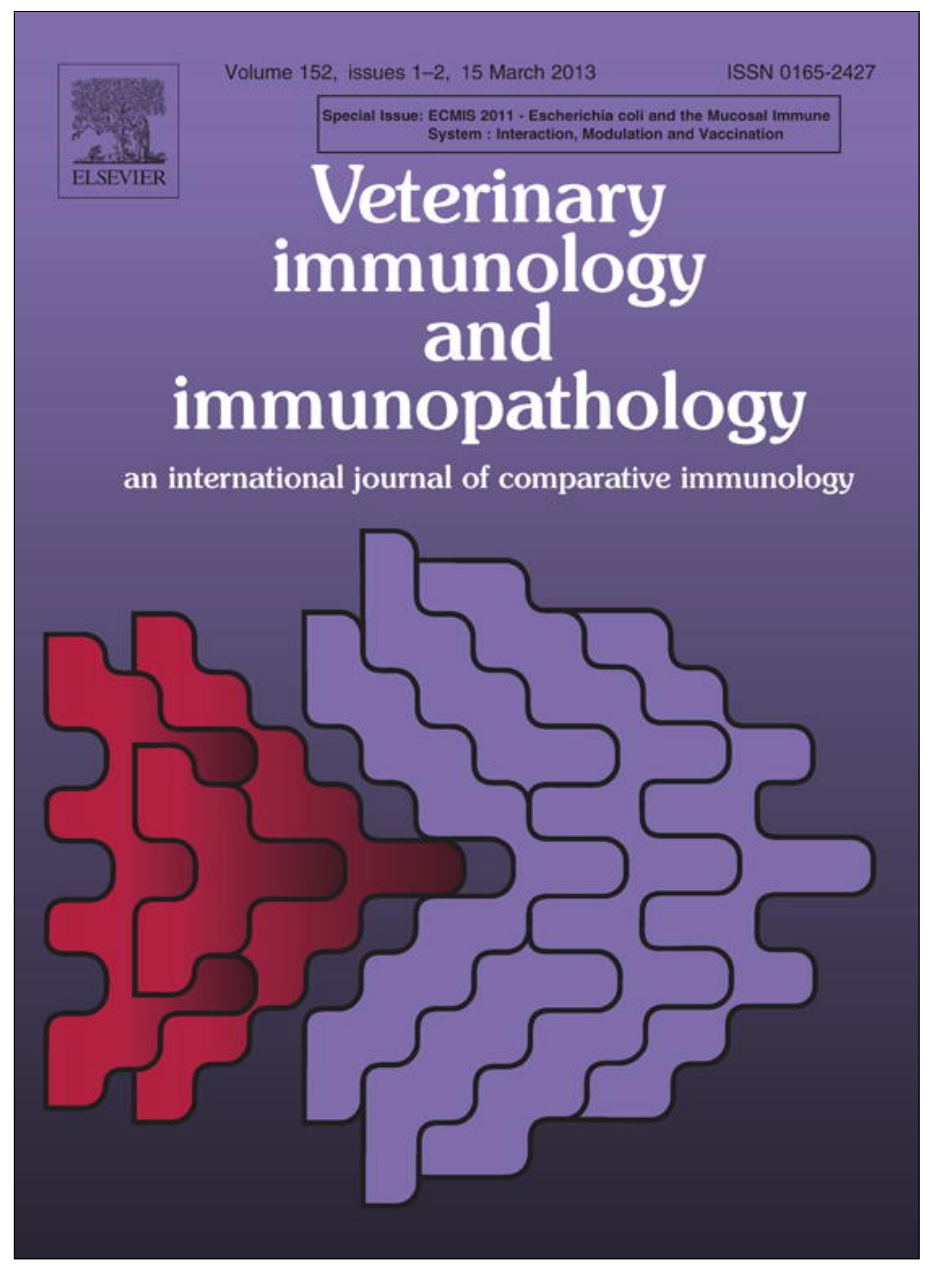

This article appeared in a journal published by Elsevier. The attached copy is furnished to the author for internal non-commercial research and education use, including for instruction at the authors institution and sharing with colleagues.

Other uses, including reproduction and distribution, or selling or licensing copies, or posting to personal, institutional or third party websites are prohibited.

In most cases authors are permitted to post their version of the article (e.g. in Word or Tex form) to their personal website or institutional repository. Authors requiring further information regarding Elsevier's archiving and manuscript policies are encouraged to visit:

http://www.elsevier.com/copyright 


\title{
Escherichia coli virulence factors
}

\author{
Jacques Mainil* \\ Université de Liège, Faculté de Médecine vétérinaire, Belgium
}

\section{A R T I C L E I N F O}

\section{Keywords:}

Escherichia coli

Virulence

Adhesins

Type 3 secretion system

Toxins

\begin{abstract}
A B S T R A C T
Escherichia coli was described in 1885 by a German pediatrician, Theodor Escherich, in the faeces of a child suffering diarrhoea. In 1893, a Danish veterinarian postulated that the $E$. coli species comprises different strains, some being pathogens, others not. Today the $E$. coli species is subdivided into several pathogenic strains causing different intestinal, urinary tract or internal infections and pathologies, in animal species and in humans. Since this congress topic is the interaction between $E$. coli and the mucosal immune system, the purpose of this manuscript is to present different classes of adhesins (fimbrial adhesins, afimbrial adhesins and outer membrane proteins), the type 3 secretion system, and some toxins (oligopeptide, AB, and RTX pore-forming toxins) produced by E. coli, that can directly interact with the epithelial cells of the intestinal, respiratory and urinary tracts.
\end{abstract}

(C) 2012 Elsevier B.V. All rights reserved.

\section{Pathogenic Escherichia coli}

Escherichia coli is a Gram-negative, rod-shaped bacterium belonging to the family Enterobacteriaceae that was described in 1885 by a German pediatrician, Theodor Escherich (1857-1911) in the faeces of a child suffering diarrhoea (Escherich, 1885). While many strains occur as commensal members of the microbiota in the intestinal tract of animals and humans, some strains are, however, important pathogens that cause a wide spectrum of diseases, ranging from self-limiting to life-threatening intestinal and extra-intestinal illnesses (Sussman, 1997; Wray and Woodward, 1997; Kaper et al., 2004; Nataro et al., 2011). This was a puzzling observation at the time, because according to the Koch's postulates (Koch, 1884), one bacterial species was either pathogen or not. In 1893, a Danish veterinarian postulated that the $E$. coli species comprises different strains, some being pathogens, others not (Jensen, 1893). Not only his assertion proved true but also $E$. coli is today subdivided into several pathogenic strains causing different intestinal, urinary tract or internal

\footnotetext{
* Tel.: +32 4 3669522; fax: +32 43664261 .

E-mail address: jg.mainil@ulg.ac.be
}

infections and pathologies, in all animal species and in humans. Those pathogenic E. coli serotypes were therefore named by the clinical syndrome they can cause (Table 1 ): diarrhoeagenic E. coli (DEC), uropathogenic E. coli (UPEC), septicaemic E. coli (SePEC), neonatal meningitis-associated E. coli (NMEC), etc.; or sometimes according to the target host: avian pathogenic E. coli (APEC) (Mainil, 2003a).

The question soon changed to how identifying in vitro the pathogenic strains of $E$. coli. The first answer came from the serotyping system developed by Kauffmann in the 1940s, i.e. the identification of somatic (O antigen), capsular (K antigen) and flagellar (H antigen) surface antigens (Kauffmann, 1947). Some serotypes are indeed more frequently than others associated with specific clinical syndromes (Sojka, 1965; Orskov and Orskov, 1992; Lior, 1994).

Fortunately from the late 1960s onwards, several specific properties that differentiate the pathogenic strains from each other and from non-pathogenic strains were unravelled. It therefore became possible to name the different classes of pathogenic E. coli on the basis of their specific properties instead of the clinical syndrome they can produce. Focusing on diarrhoeagenic E. coli, three classes were so defined in humans in the 1970s (World Health Organization, 1980) (Table 1): enterotoxigenic E. coli (ETEC) producing (entero)toxins causing 


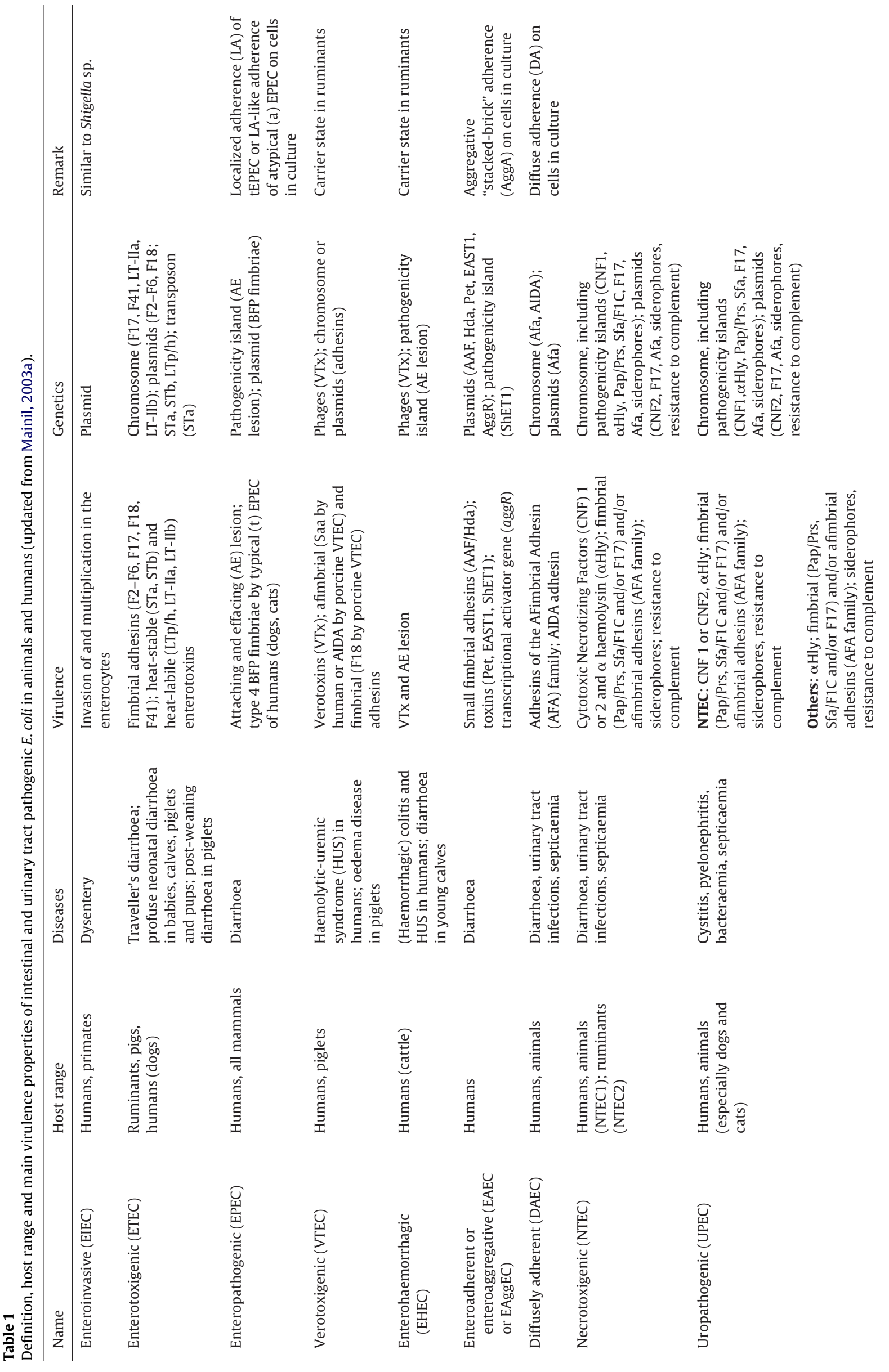




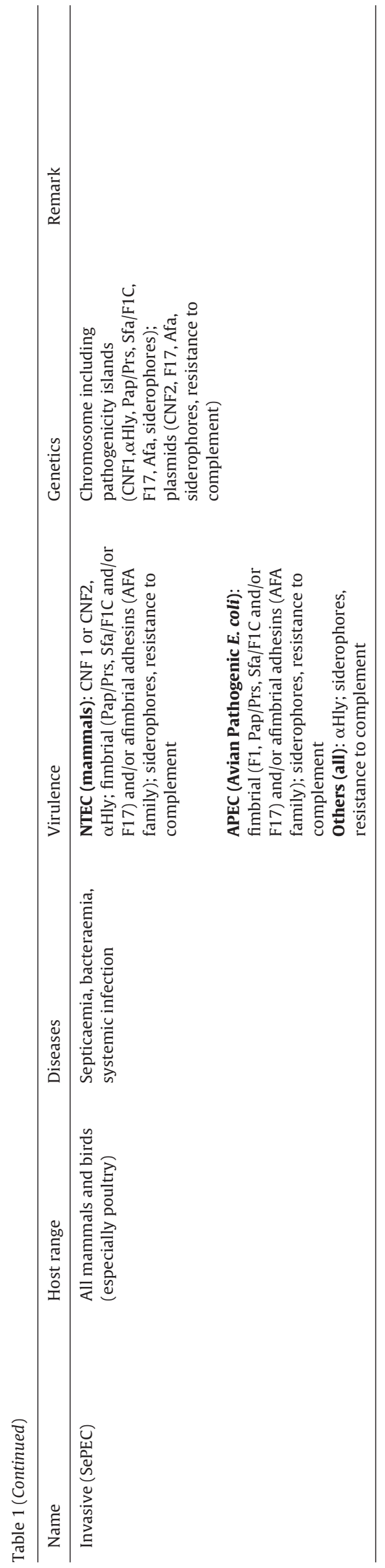

hypersecretion of electrolytes and water by enterocytes of domestic animals and humans, enteroinvasive E. coli (EIEC) invading the enterocytes of humans and primates, and enteropathogenic $E$. coli belonging to specific serotypes, pathogenic for humans, but whose virulence properties were still unknown at the time.

More properties of DEC were progressively discovered in the 1980s and 1990s and more classes were named on the basis of adherence and/or toxic properties (Table 1): attaching-effacing $E$. coli (AEEC), diffusely adherent $E$. coli (DAEC), enteroaggregative E. coli (EAEC), Shiga/Verotoxigenic E. coli (VTEC), necrotoxigenic E. coli (NTEC), diarrhoea-associated haemolytic E. coli (DHEC), and still others. But some names still referred to history, like enteropathogenic E. coli (EPEC) sensu stricto, and others to clinical syndromes, like enterohaemorrhagic E. coli (EHEC) (Table 1). Therefore some names are today obsolete, while some strains received different names based on the clinical syndromes, the host target species and/or their virulence properties, respectively. Several review articles on the E. coli pathotypes in humans and animals have been published more or less recently (Nataro and Kaper, 1998; De Rycke et al., 1999; Dho-Moulin and Fairbrother, 1999; Nagy and Fekete, 1999; Kaper et al., 2004; Mainil and Daube, 2005; Gyles and Fairbrother, 2010).

Since the topic of the ECMIS congress is the interaction between $E$. coli and the mucosal immune system, the purpose of this manuscript is to give an overview of the most important virulence-associated properties of E. coli that can directly interact with the epithelial cells, i.e. adherence factors and "exotoxins". The adherence to the epithelial cells is mediated by surface structures or molecules, like the fimbrial adhesins, the afimbrial adhesins and/or outer membrane proteins (OMPs). The "exotoxins" (so-called although not all are actually excreted in the extracellular environment) are proteins that can target either the cell skeleton (type 3-secreted effectors), or the cell metabolism (intracellular AB toxins with enzymatic activity; oligopeptide toxins activating a metabolic cascade after fixation on the cell cytoplasmic membrane), or the cell cytoplasmic membrane (enzymatic and pore-forming cytolysins).

\section{The adhesins and colonization factors}

At least three different general classes of $E$. coli adhesins can be defined: different appendices like fimbriae, fibrillae and curli, the afimbrial family (Afa), and specific outer membrane proteins (OMPs) like the intimin (Kaper et al., 2004; Mainil, 2005a).

\subsection{The appendices}

Duguid et al. (1955) described electron microscope visible appendices responsible for the agglutination of erythrocytes by some E. coli strains, that they named "fimbriae" (=thread, fringe or fibre in Latin). At the beginning those appendices also received the name of "pili", but today it is advised to give the latter name only the appendices involved in plasmid conjugation. In addition, it soon became obvious that several classes of fimbrial appendices existed and several classifications 
have been proposed, none of them being fully satisfying. Orskov and Orskov (1990) proposed four classes of appendices on the basis of their ultra-structure: rigid, thick $(5-7 \mathrm{~nm})$ with a central hole, peritrichous appendices or fimbriae sensu stricto; flexible, thin $(2-3 \mathrm{~nm})$ with no axial hole, peritrichous appendices or fibrillae (=thin, small fibres in Latin); flexible, moderately thick (4-6 nm), bundle- or rope-forming, polar appendices or type 4 fimbriae (this name is a heritage from previous classifications); and highly flexible, very thin, aggregated appendices or curli (=curve, spiral, loop in Latin).

Those appendices are shafts protruding from the bacterial cell surface and comprise different proteins ( $\mathrm{Wu}$ and Fives-Taylor, 2001; Bann et al., 2002; Clarke et al., 2003; Mainil, 2003a, 2005a; Barnhart and Chapman, 2006). Structurally the shaft is made of several hundreds copies of a protein, whose generic name is "major subunit" of a molecular weight between 15 and $20 \mathrm{kDa}$, but that received different other names according to the actual appendix (pilin, fimbrin, or curlin f.i.). Several other proteins, present in one or a very few copy number and called "minor proteins", are present either at the basis or at the top of the shaft or intercalated between the "major subunits". The minor subunits present at the basis anchor the shaft within the outer membrane of $E$. coli. The adherence property of the appendices, i.e. the actual interaction between the bacterial adhesin and the eukaryotic receptor, can be mediated (i) by a specific minor subunit protein present in one copy at the top of the shaft or in several copies intercalated between the major subunit proteins; or (ii) by a domain of the major subunit protein itself, either only the copy present at the top of the shaft or several copies along the shaft. Appendices involved in adherence to host cells and tissues are grouped into families according to their receptor primary specificity (=macroevolution), usually the carbohydrate moiety of glycoproteins or glycolipids, but also peptide sequences. Members within each family can also have subtle differences in the actual identity of their oligosaccharide or oligopeptide receptors sometimes leading to different tissue and/or host specificity (=microevolution).

E. coli fimbriae and fibrillae adhesins were at first described on enterotoxigenic E. coli (ETEC) from pigs, calves and then humans (Nataro and Kaper, 1998; Nagy and Fekete, 1999; Kaper et al., 2004; Gyles and Fairbrother, 2010). They were thereafter also described on uropathogenic (UPEC), septicaemic (SePEC), avian pathogenic (APEC) and necrotoxigenic (NTEC) E. coli (Table 1) (Donnenberg and Welch, 1996; De Rycke et al., 1999; Dho-Moulin and Fairbrother, 1999; Mainil et al., 1999; Wu and Fives-Taylor, 2001; Stordeur et al., 2002; Mainil, 2003a). They received different names at the time of their description, but today most are named by the letter F followed by numbers (Orskov and Orskov, 1990): F2 (Colonization Factor Antigen (CFA) 1), F3 (CFA2), F4 (K88 antigen), F5 (K99 antigen), F6 (987 strain pili), F18 (F107, 8818, 2134 pili), F41 (B41 strain fimbriae) of ETEC; F7-F16 (Pap/Prs fimbriae) of UPEC, SePEC, APEC, NTEC; F1 (type 1) causing mannose-sensitive haemagglutination, produced by almost all strains of $E$. coli and probably involved in the early steps of the colonization of the air sacs by APEC; F17 (FY, Att25, Att111, Vir adhesin) produced by different
ETEC, SePEC, UPEC, APEC, and NTEC. The genes coding for the different fimbriae and fibrillae can be plasmid-located, especially in ETEC or chromosome-located sometimes on specific pathogenicity islands, like in UPEC (Johnson, 1991; Nataro and Kaper, 1998; Nagy and Fekete, 1999; Mainil, 2003a; Johnson, 2003; Kaper et al., 2004; Mainil, 2005a; Nataro, 2005; Rasko et al., 2008; Gyles and Fairbrother, 2010).

The E. coli best known type 4 fimbriae, or Bundle-Forming Pili (BFP) are produced by typical enteropathogenic $E$. coli (tEPEC) (Table 1), a sub-class of human EPEC (Wu and Fives-Taylor, 2001; Clarke et al., 2003; Bardiau et al., 2010). Non BFP-producing EPEC from humans and animals are called atypical (a) EPEC (Nataro and Kaper, 1998; Trabulsi et al., 2002; Kaper et al., 2004; Hernandes et al., 2009). The BFP, that are encoded by plasmid-located genes, were at first thought to be involved in adherence to the human enterocytes, but are today believed to help bacteria to stick together forming micro-colonies at the surface of the host cells, also called "Localized Adherence" (LA) pattern (Scaletsky et al., 1984; Nataro and Kaper, 1998; Kaper et al., 2004). Other type 4-like fimbriae, the Longus Pilus, are produced by some human ETEC strains that, in addition to promoting intestinal colonization, may also play a role in the protection of the bacteria from antimicrobial agents (Giron et al., 1997; Clavijo et al., 2010).

Curli that are encoded by chromosome-located genes, are produced by different pathogenic $E$. coli strains, more especially SePEC and some EHEC. Curli may be involved in the adherence of SePEC to the mucosal extracellular matrix after fragilization of the epithelium and in the formation of biofilm on organic (not only animals, but also plants) and non-organic surfaces by 0157:H7 EHEC and other pathogenic strains. But more studies are needed, especially in vivo to more precisely understand their role in $E$. coli pathogenicity (Wu and Fives-Taylor, 2001; Barnhart and Chapman, 2006; Goulter et al., 2009; Saldana et al., 2011).

All fimbriae are good immunogens since the major subunit is a $15-25 \mathrm{kDa}$ protein and is present in several hundreds of copies. Vaccination of the pregnant dams to protect newborn calves, lambs and piglets against infections by ETEC via colostral antibodies is actually based on vaccines containing (semi-)purified fimbriae (F4, F5, F6, F17 and/or F41) (Nagy and Fekete, 1999; Radostits et al., 2007). But no other vaccine with proved value is currently available to our knowledge.

\subsection{The afimbrial family of adhesins}

Duguid et al. (1955) had already observed that several appendix non-producing $E$. coli strains could also cause the agglutination of erythrocytes. Those haemagglutinins actually form a family of genetically related different adhesins, the AFimbrial adhesin (Afa) family regrouping Afa, Dr, M, $\mathrm{Nfa}, \mathrm{F} 1845$ and AAF variants. Afimbrial adhesins of the Afa family are encoded by plasmid- or chromosome-located genes, according to the variant, but also sometimes within one variant (Law and Chart, 1998; Le Bouguénec and Bertin, 1999; Mainil, 2003a, 2005a; Servin, 2005; Harrington et al., 2006). While some members of the family are true afimbrial 
adhesins (Afa, Dr, M), others form small fibrillae (F1845, AAF), and still others capsule-like structures surrounding the bacterial cell (Nfa). The structure of the true afimbrial adhesins can be compared to truncated fimbriae with no major subunit, but only the minor subunits of the basis and the adhesin subunit. One of the minor-like subunits is an invasin participating to the invasion of cells in cultures (Le Bouguénec and Bertin, 1999; Servin, 2005).

With the exception of AAF-positive strains, afimbrial adhesin-producing $E$. coli display a diffuse adherence (DAEC) pattern on cells in cultures, Hep-II, HeLa, or MDCK, according to the variant (Scaletsky et al., 1984; Le Bouguénec and Bertin, 1999; Servin, 2005). The receptor for most afimbrial adhesins produced by human strains is the protein moiety of the Decay-Accelerating factor (DAF), a glycoprotein distributed on human haemopoeitic endothelial, intestinal and urinary cells. On the other hand the only so far recognized afimbrial adhesin produced by pathogenic $E$. coli from animals (Afa-VIII, related to the M afimbrial adhesin of some human UPEC) does not recognize DAF as a receptor and does not adhere to Hep-II or HeLa cells (Lalioui et al., 1999; Le Bouguénec and Bertin, 1999; Mainil, 2003a, 2005a; Servin, 2005). Other receptors for Afa and Dr adhesins of human DAEC are type IV collagen and CEACAMs (CarcinoEmbryonic Antigens-related CellAdhesion Molecules) (Servin, 2005). The DAEC strains are associated with urinary tract (UPEC), intestinal tract (DEC) and invasive (SePEC) infections in humans, different other mammalian species and poultry (APEC) (Table 1) (Mainil et al., 1997, 1999, 2001; Le Bouguénec and Bertin, 1999; Gérardin et al., 2000; Stordeur et al., 2002; Servin, 2005).

AAF adhesins are small fibrillae (Harrington et al., 2006) and AAF-positive E. coli strains do not display the DA pattern, but the aggregative (or 'stacked-brick') adherence pattern on Hep-II and HeLa cells (Levine, 1987; Flores and Okhuysen, 2009). Those strains were named enteroadherent $E$. coli (EAEC), but are today named enteroaggregative $E$. coli (EAggEC) (Table 1) (Levine, 1987; Law and Chart, 1998). AAF fibrillae promote auto-agglutination of EAggEC and also mediate bacterial adherence to extracellular matrix proteins, more precisely fibronectin, laminin, and collagen IV (Nataro, 2005; Harrington et al., 2006; Huang et al., 2006; Weintraub, 2007; Farfan et al., 2008; Flores and Okhuysen, 2009). But the aggregative adherence pattern actually encompasses both pathogenic and non-pathogenic $E$. coli strains. Pathogenic EAggEC represent emerging specific human pathogens responsible for acute or persistent diarrhoea in children and adults worldwide (Levine, 1987; Huang et al., 2006; Weintraub, 2007; Flores and Okhuysen, 2009). In vivo pathogenic EAggEC not only adhere to enterocytes and to the extracellular intestinal matrix, but also form mucoid biofilms at the surface of the intestinal epithelium of the terminal ileum and of the colon (Nataro, 2005; Weintraub, 2007; Farfan et al., 2008). The recent outbreak of haemorrhagic colitis and haemolytic-uremic syndrome in Germany was caused by one EAggEC having acquired the genes coding for a verotoxin (see Section 4 ) by horizontal transfer by phage transduction (Piérard et al., 2012; Bielaszewska et al., 2011; Scheutz et al., 2011). Such AAFpositive $E$. coli strains have not been described in animals yet.

\subsection{Outer membrane proteins (OMPs)}

Different specific OMPs of pathogenic E. coli strains are also involved in bacteria-eukaryotic cell adherence, bacteria-bacteria adherence and/or biofilm formation (Table 1): the plasmid-encoded Adhesin Involved in Diffuse Adherence (AIDA) of human and porcine ETEC and VTEC (Niewerth et al., 2001; Mainil et al., 2002; Sherlock et al., 2004; Bardiau et al., 2010), the chromosome or plasmid-encoded Porcine Attaching-and-effacingAssociated adhesin (Paa) of porcine EPEC and ETEC and of human 0157:H7 EHEC (An et al., 1999; Amezcua et al., 2002; Leclerc et al., 2007; Hernandes et al., 2009; Bardiau et al., 2010), the plasmid-encoded Shigatoxigenic Autoagglutinating Adhesin (Saa) of human and bovine VTEC (Jenkins et al., 2003; Bardiau et al., 2010), and the chromosome-encoded intimin adhesin (Int) of human and animal EPEC and EHEC (Clarke et al., 2003; Mainil, 2005a; Hernandes et al., 2009), for instance.

The intimin adhesin is a $94 \mathrm{kDa}$ OMP encoded by a gene (eae) located on a pathogenicity island named Locus of Enterocyte Effacement (LEE) along with other genes coding for the formation of the Attaching and Effacing (AE) lesion produced by EPEC and EHEC (Nataro and Kaper, 1998; Clarke et al., 2003; Mainil, 2005a; Hernandes et al., 2009). Different types of intimin adhesins have been described that differ in their amino-acid carboxy terminal sequence. These intimins are designated by Greek letters and correlated to the EHEC and EPEC serotypes (Oswald et al., 2000; Schmidt, 2010). The other LEE-located genes code for a type 3 secretion system (T3SS) and for type 3-secreted effectors into the eukaryotic cell (see Section 3).

One of the type 3-secreted effectors is the Tir (Translocated Intimin Receptor) protein that can have different functions after incorporation into the enterocyte cytoplasmic membrane, including serving as a receptor for the intimin adhesin. The Tir protein exhibits a hairpin conformation with the extracellular loop binding to the intimin and the amino- and carboxy-terminal domains projecting into the host cells and interacting with the actin network of the cytoskeleton to form the AE lesion. Different types of Tir proteins have also been described. Since the interaction between intimin and Tir is located in the 280 carboxy terminal amino-acids of the intimin adhesin, the different intimin types specifically interact with their cognate Tir receptor (China et al., 1999; Hartland et al., 1999; Luo et al., 2000; Karmali et al., 2010; Schmidt, 2010). Alternative host receptors for the intimin adhesin are $\beta 1$ integrins and nucleolin (Garmendia et al., 2005).

\section{The type 3 secretion system (T3SS)}

One important characteristic of EPEC and EHEC strains is their ability to provoke the disappearance of the enterocyte microvilli and to intimately attach to the nude cytoplasmic membrane of the enterocyte (AE lesions). AE lesions are the results of a profound disorganization of the actin filaments of the eukaryotic cell skeleton and of their re-organization beneath the intimately attached bacteria to form pedestals (Nataro and Kaper, 1998; Clarke et al., 2003; Kaper et al., 
2004; Garmendia et al., 2005; Mainil and Daube, 2005; Moxley and Smith, 2010; Schmidt, 2010; Bolton, 2011).

A large bacterial chromosomal pathogenicity island, the locus of enterocyte effacement (LEE), carries all (or almost all according to the seropathotypes) genes necessary for the formation of the AE lesions. They are grouped into several functional gene clusters, the most important being: the $\operatorname{esp} A, B, D$ genes coding for the type 3 secretion system (T3SS) structural proteins (or injectisome); the esc/sep genes coding for the anchor structure of the injectisome within the outer and inner bacterial membranes; the tir and several other genes coding for the type 3-secreted effectors into the eukaryotic cells; and the eae gene coding for the intimin adhesin located within the bacterial outer membrane (see Section 2.3) (Clarke et al., 2003; Garmendia et al., 2005; Mainil and Daube, 2005; Moxley and Smith, 2010; Schmidt, 2010; Bolton, 2011).

The injectisome is composed of polymerized EspA protein with the EspB and EspD proteins at the top forming a pore within the eukaryotic cytoplasmic membrane. To some extent the injectisome functions as one adhesin connecting the bacteria to the eukaryotic cells, through which the type 3-secreted effectors translocate into the enterocytes (China and Goffaux, 1999; Clarke et al., 2003; Garmendia et al., 2005; Schmidt, 2010).

\section{The exotoxins}

The first toxins ( $\tau \mathrm{O} \xi$ เко $\nu=$ poison $)$ were described at the end of the 19th century: the diphtheria toxin in 1888 by Roux and Yersin, the tetanus toxin in 1890 by Faber and the botulinum toxin in 1898 by van Ermengen. Today several classes of bacterial toxins are described according to structural and functional criteria: (i) oligopeptide toxins interfering indirectly with the eukaryotic cell metabolism by activating an intracellular cascade after binding to their receptor on the cytoplasmic membrane; (ii) AB toxins directly interfering with the eukaryotic cell structure or metabolism after receptor-mediated endocytosis; (iii) enzymatic and RTX pore-forming cytolysins perturbing the eukaryotic cell cytoplasmic membrane; (iv) type 3secreted effectors (see Section 3) (Mainil, 2003b, 2005b).

\subsection{The oligopeptide toxins}

Several bacterial species produce oligopeptide toxins, like E. coli, Vibrio cholerae, Yersinia enterocolitica, Klebsiella pneumoniae, and Enterobacter aerogenes (Mainil, 2005b). E. coli even produces different oligopeptide toxins, like the heat-stable enterotoxins of enterotoxigenic strains (STaP, STaH and STb) and the heat-stable enterotoxin of enteroaggregative strains (EAST1) (Smith and Halls, 1967; Burgess et al., 1978; Moseley et al., 1983; Savarino et al., 1993). STaP and STaH are 18 and 19 amino-acid peptides respectively of a molecular weight of less than $2 \mathrm{kDa}$ (Moseley et al., 1983), whereas STb is a 48 amino-acid peptide of ca. $5 \mathrm{kDa}$ (Dubreuil, 2008) and EAST1 is a 38 amino-acid toxin of $c a$. $4 \mathrm{kDa}$ (Savarino et al., 1993). Because of their low molecular weight, no oligopeptide toxin is a good immunogen.

STaP is produced by animal (bovine, ovine, porcine and canine) and human ETEC strains, while STaH is produced only by human ETEC strains, STb by porcine ETEC strains, and EAST1 by human EAggEC and by bovine, human and porcine ETEC, EPEC, VTEC strains (Table 1) (Wasteson et al., 1988; Mainil et al., 1998a; Nataro and Kaper, 1998; Nagy and Fekete, 1999; Kaper et al., 2004; Nataro, 2005; Weintraub, 2007; Gyles and Fairbrother, 2010). All STaP-, STaH-, STb- and EAST1-encoding genes are plasmidlocated (Gyles et al., 1974; Mainil et al., 1992, 1998b; Mainil, 2002; Nataro, 2005; Weintraub, 2007; Gyles and Fairbrother, 2010). STaH, STaP, and probably EAST1 (based on structural similarity), exert their toxicity via activation of an intra-cellular cascade (Sears and Kaper, 1996; Kaper et al., 2004; Gyles and Fairbrother, 2010), while STb seems to act as a non-specific pore-forming toxin (Gonçalves et al., 2007; Dubreuil, 2008). If newborn calves, lambs, piglets and babies in developing countries are sensitive to the action of STaP and/or STaH that can also be involved in traveller's diarrhoea, the in vivo roles of STb and EAST1 are still controversial (Nataro and Kaper, 1998; Nagy and Fekete, 1999; Kaper et al., 2004; Dubreuil, 2008; Gyles and Fairbrother, 2010; Konno et al., 2011).

Both STaP and STaH are synthesized as a pre-protoxin of 72 amino acids that is secreted by a type 2 secretion system (general or Sec-dependent secretion pathway) (China and Goffaux, 1999) into the periplasmic space of the bacteria after removal of the 18 amino-acid long signal sequence. Further processing occurs in the periplasmic space or during the crossing of the outer membrane to produce the active 18 (STaP) or 19 (STaH) amino-acid toxins with three disulfide bonds (Rasheed et al., 1990; Sears and Kaper, 1996). The receptor of both STa is a transmembrane glycoprotein with guanylate cyclase activity (guanylyl cyclase C) of the intracytoplasmic domain, that is present at the height of the microvilli of the enterocytes (Nataro and Kaper, 1998; Nagy and Fekete, 1999; Kaper et al., 2004; Gyles and Fairbrother, 2010). The intracellular levels of cyclic guanosine monophosphate (cGMP) regulate several cellular processes including the activity of ion pumps, like the main ion channel of epithelial cells (the cystic fibrosis transmembrane conductance regulator: CTFR). The action of either STa results in the stimulation of chloride and water secretion and the inhibition of sodium absorption, leading to watery diarrhoea.

\subsection{The $A B$ toxins}

Some bacterial AB toxins (Mainil, 2005b) are actually composed of two separate subunits, with one copy of the A subunit and one to several copies of the B subunit. Other $A B$ toxins are actually single proteins composed of two domains corresponding to the $A$ and $B$ subunits. The $A$ subunit/domain is the toxic component and the B subunit(s)/domain binds the whole toxins to the receptors on the eukaryotic cell membrane. After activation by enzymatic cleavage, the A subunit/domain can exert its toxic (enzymatic) activity: interference with the cytoskeleton integrity, the protein synthesis, the DNA metabolism, or different secretion pathways.

As examples, two types of $\mathrm{AB} E$. coli toxins whose interactions with eukaryotic cells are well understood and whose role in vivo has been proved are going to 
be described: the heat-labile enterotoxin (LT) of human, porcine and ruminant ETEC and the Vero/Shiga toxins (VTx/Stx) of human, porcine and bovine EHEC and VTEC.

\subsubsection{The heat-labile enterotoxins}

Besides the STa and STb oligopeptide enterotoxins (see Section 4.1), porcine and human ETEC strains can also produce an $A_{1} B_{5}$ heat-labile enterotoxin or LT (Table 1) (Gyles and Barnum, 1969; Honda et al., 1981). Porcine and human LT (LTp and LTh) are both related to the cholera toxin (CT) of Vibrio cholerae (Clements and Finkelstein, 1978) but slightly differ antigenically from each other (Honda et al., 1981). Genes coding for LTp and LTh are located on plasmids (Gyles et al., 1974; Mainil et al., 1998b; Nataro and Kaper, 1998; Nagy and Fekete, 1999; Kaper et al., 2004; Nataro, 2005; Weintraub, 2007; Gyles and Fairbrother, 2010).

LT are secreted by the type 2 secretion system (China and Goffaux, 1999) involving the removal of the signal sequences. After binding of the B subunits to their specific receptors (the main receptor of $\mathrm{LT}$ and $\mathrm{CT}$ is ganglioside GM1) on the host cells, whole LT are internalized by receptor-mediated endocytosis and begin a retrograde transport in the endocytic vesicles to the endoplasmic reticulum via the Golgi apparatus. There the A subunit is enzymatically cleaved into a large A1 and a small A2 fragments and the A1 fragment translocates into the cytoplasm. The enzymatic activity of the A1 fragment is NAD-dependent ADP-ribosylation of the stimulatory regulator of the enzyme adenyl cyclase, causing its permanent activation and high levels of cyclic adenosine monophosphate (cAMP) in the target cells. The action of LT also results in the opening of the cystic fibrosis transmembrane conductance regulator (CTFR) with increased secretion of chloride and carbonate ions and of water and in the inhibition of sodium absorption, leading to watery cholera-like diarrhoea. Newborn and weaned piglets and humans in developing countries are especially sensitive to the action of LT that can also be involved in traveller's diarrhoea cases (Nataro and Kaper, 1998; Nagy and Fekete, 1999; Kaper et al., 2004; Gyles and Fairbrother, 2010).

Two other LT enterotoxins (LT-IIA and LT-IIb) that differ from LTp/h and CT antigenically and by their main receptor specificity (GD1b for LT-IIA and GD1a for LT-IIb), but that possess similar enzymatic activity, can be produced by E. coli isolated from humans, bovines and water buffaloes suffering diarrhoea (Table 1). The genes coding for LTIIa and LT-IIb are chromosome-located (Guth et al., 1986; Holmes et al., 1986; Pickett et al., 1986; Fukuta et al., 1988; Pickett et al., 1989).

All LT enterotoxins are very good immunogens and LTp is present in vaccines against neonatal diarrhoea in piglets (Nagy and Fekete, 1999; Radostits et al., 2007).

\subsubsection{The Vero/Shiga toxins}

In 1977, Konowalchuk et al. (1977) observed in vitro that culture supernatants of some $E$. coli isolates produced a profound cytotoxic effect on Vero cells. Two distinct Verotoxin (VTx) families have been described, VTx1 and
VTx2. VTx1 is nearly identical to the Shiga toxin of Shigella dysenteriae serotype 1 and the term Shiga toxin (Stx) was also proposed to design this group of cytotoxins (O'Brien et al., 1982). In addition, three variant forms of VTx1 and seven variant forms of VTx2 have been described, called VTx1a, VTx1c, VTx1d and VTx2a through VTx2g, respectively (Scheutz et al., 2012). VTx are produced by human, porcine and bovine VTEC and EHEC (Table 1). Strains producing VTx2a, VTx2c and/or VTx2d are more often associated with the haemolytic-uremic syndrome (HUS) in humans while VTx2e is associated with oedema disease in swine (Mainil and Daube, 2005; Gyles and Fairbrother, 2010; Johannes and Romer, 2010; Karmali et al., 2010; Pennington, 2010; Sandvig et al., 2010; Bolton, 2011). The majority of VTx are encoded by phage-located genes that can be lost or acquired by other E. coli not only in vitro, but also in vivo (Karch et al., 1992; Toth et al., 2003; Bielaszewska et al., 2007).

VTx are also $A_{1} B_{5}$ toxins using Gb3, or Gb4 for VTx2e, as cell surface receptors, but their target cells in vivo are not the enterocytes. VTx can indeed cross the human and porcine intestinal epithelium by transcytosis through the enterocytes, i.e. endocytosis followed by exocytosis at the basal pole. Still, the actual mechanism of crossing is not fully understood and may differ between humans and piglets since the human enterocytes do not express the Gb3 receptor (Björk et al., 1987; Philpott et al., 1997; Hurley et al., 1999) while porcine enterocytes do express the Gb4 receptor (Waddell et al., 1996).

In humans, and also probably in piglets, VTx subsequently travel in the blood stream in association with leucocytes and attach to the receptors on the endothelial cells, more especially of the renal glomerulus vessels in humans, but of vessels all over the body in pigs. After internalization, the whole toxin begins a retrograde transport in the endocytic vesicles to the endoplasmic reticulum via the Golgi apparatus where the A subunit is enzymatically cleaved. Thereafter the activated A1 fragment translocates into the cytoplasm and cleaves the $28 \mathrm{~S}$ rRNA via N-glycosylation of a specific adenine residue. The protein synthesis is inhibited in the endothelial cells and the blood vessel walls are damaged. VTx eventually provoke thrombotic microangiopathy, leading to haemolysis, thrombocytopaenia and renal failure in humans (=HUS syndrome) (Mainil and Daube, 2005; Johannes and Romer, 2010; Karmali et al., 2010; Sandvig et al., 2010; Bolton, 2011 ) or to extra-vasation in piglets (=oedema disease) (Nagy and Fekete, 1999; Gyles and Fairbrother, 2010).

VTx-producing $E$. coli strains can also colonize the intestines of ruminants, though VTx cause no vascular lesion and no disease in ruminants (=healthy carriers) for at least two reasons. At first VTx do not cross the intestinal epithelium though bovine crypt enterocytes express the Gb3 receptor (Hoey et al., 2002). Indeed after endocytosis the intracellular trafficking localizes VTx in lysosomes leading to abrogation of transcytosis (Hoey et al., 2003). Moreover the $\mathrm{Gb} 3$ receptor is not expressed on endothelial cells of cattle (Pruimboom-Brees et al., 2000; Hoey et al., 2002).

VTx are good immunogens and active immunization with a VTx2e toxoid can protect piglets against oedema 
disease (Johansen et al., 1997), though no actual vaccine has been marketed yet.

\subsection{The RTX pore-forming toxins}

RTX (Repeats in ToXins) toxins are a class of cytolysins causing eukaryotic cell death and lysis by forming a pore within the cytoplasmic membrane. These large proteins (100-200 kDa) are phylogenetically related toxins produced by Gram-negative bacteria, characterized by the presence of nanopeptide repeats near the carboxylterminus that bind $\mathrm{Ca}^{2+}$ and are necessary for full toxic activity, and secreted into the culture supernatant by a type 1 secretion system (China and Goffaux, 1999). The most representative are the leucotoxins/haemolysins of Mannheimia haemolytica (Lkt), Actinobacillus pleuropneumoniae (Apx), Morganella morganiii (Mmx), and Moraxella bovis, whose role in the pathogenesis of the infection has been demonstrated (Oxhamre and Richter-Dahlfors, 2003; Mainil, 2005b). But the first described RTX toxin is the $107 \mathrm{kDa} 1024$ amino-acid long E. coli $\alpha$ haemolysin (Kayser, 1903 ) that is today one of the most studied RTX toxins.

The $\alpha$ haemolysin (or HlyA) is produced by several pathogenic types of $E$. coli causing extra-intestinal (cystitis, nephritis, meningitis, septicaemia in humans and animals) and intestinal (enteritis and enterotoxaemia in piglets) infections, more especially NTEC, ETEC, and VTEC strains, but sometimes also by strains not belonging to any classical pathotype (Table 1 ). The gene clusters encoding the HlyA can be located on the chromosome, sometimes as part of pathogenicity islands more especially in NTEC1 and UPEC, or on plasmids, more especially in porcine ETEC and VTEC strains (Table 1) (Bertschinger and Gyles, 1994; Hampson, 1994; Nataro and Levine, 1994; Ludwig and Goebel, 1997; De Rycke et al., 1999; Dozois and Curtiss, 1999; Mainil et al., 1999; Mainil, 2003b).

The actual role of HlyA in the pathogenesis of $E$. coli is still a question of debate. Contradictory results were obtained in early experiments, but recombinant DNA techniques to produce allelic mutants provided more direct evidence that HlyA plays some role in extra-intestinal infections: HlyA is not sufficient for virulence, but enhances the virulence of exraintestinal pathogenic $E$. coli in the presence of other pathogenic traits. However the results still depends on the experimental models and the precise role of HlyA remains unclear. Conversely, there exists no evidence at all that HlyA plays any role in intestinal infections (Gyles, 1994; Ludwig and Goebel, 1997; Mainil, 2003b; Oxhamre and Richter-Dahlfors, 2003).

An Hly-related ( $>60 \%$ genetic homology) haemolysin of $E$. coli is the enterohaemolysin (or EhxA) that is active only on washed sheep red blood cells and is produced by aEPEC, VTEC, and EHEC strains. Several alleles have been described, some being associated more specifically with VTEC strains, and others with aEPEC and EHEC strains. The EhxA-encoding genes are located on a plasmid. But the question of the role of EhxA in the pathogenesis of those strains remains unresolved, although antibody can be detected in humans infected with Ehx-positive EHEC (Beutin et al., 1988; Gyles, 1994; Ludwig and Goebel, 1997; Mainil and Daube, 2005; Cookson et al., 2007).

\section{Discussion}

Bacterial vaccines can comprise either whole cells of bacterial strains with suspected pathogenicity or bacterial extracts of virulence factors. Either vaccine type has got advantages and disadvantages: the former contains all bacterial immunogens, but blindly include strains of unknown virulence mechanisms; the latter targets the precise virulence mechanisms, but may not include all pathogenic strains and some virulence factors are no good immunogens. Moreover to be recognized as an actual virulence factor, a bacterial property must respond to the definitions of the four molecular Koch's postulates (Falkow, 1988). The fourth of these postulates reads as follows: "Specific antibodies must be produced and confer at least partial protection". With the huge technical development in the molecular field, whole genome sequencing of bacteria is a matter of hours, without mentioning the possibility to study whole bacterial populations (metagenomics). But, however this progress is necessary to help us to better know the fundamentals of the bacterial world, medical bacteriologists still need to go back to the basics in bacterial pathogenicity and to in vivo reproduction of the diseases in animal models to identify and understand bacterial pathogens and their actual virulence factors. Only then can we begin to work at the vaccinology level.

\section{Conflict of interest statement}

The author declares that the research was conducted in the absence of any commercial or financial relationships that could be construed as a potential conflict of interest.

\section{Acknowledgements}

The author would like to acknowledge the financial support of his research work on pathogenic Escherichia coli by the following institutions: "Institut pour l'encouragement de la Recherche Scientifique dans l'Industrie et l'Agriculture (IRSIA)", "Ministère des Classes moyennes et de l'Agriculture DGVI", and "Service public federal de Santé publique, Sécurité de la Chaîne alimentaire et Environnement" at the Belgian federal level; the "Fonds National de la Recherche scientifique" and the "Conseil de la Recherche de l'Université de Liège" at the regional level; and the European Commission at the European level. The author would also like to thank all the Belgian and foreign collaborators within each of these research projects, too numerous to be individually acknowledged. The author warmly thanks the former head of the laboratory of Bacteriology of the Department of Infectious Diseases of the Veterinary Faculty, University of Liège, Professor Albert Kaeckenbeeck, to whom this review is dedicated.

\section{References}

Amezcua, R., Friendship, R.M., Dewey, C.E., Gyles, C., Fairbrother, J.M., 2002. Presentation of postweaning Escherichia coli diarrhea in southern Ontario, prevalence of hemolytic E. coli serogroups involved, and their antimicrobial resistance patterns. Can. J. Vet. Res. 66, 73-78. 
An, H., Fairbrother, J.M., Desautels, C., Harel, J., 1999. Distribution of a novel locus called Paa (porcine attaching and effacing associated) amongenteric Escherichia coli. Adv. Exp. Med. Biol. 473, 179-184.

Bann, J.G., Dodson, K.W., Frieden, C., Hultgren, S.J., 2002. Adhesive pili of the chaperone-usher family. In: Donnenberg, M.S. (Ed.), Escherichia coli: Virulence Mechanisms of a Versatile Pathogen. Academic Press, San Diego, CA, U.S.A., pp. 289-306.

Bardiau, M., Szalo, M., Mainil, J.G., 2010. Initial adherence of EPEC, EHEC and VTEC to host cells. Vet. Res. 41, 57-72.

Barnhart, M.M., Chapman, M.R., 2006. Curli biogenesis and function. Ann. Rev. Microbiol. 60, 131-147.

Bertschinger, H.U., Gyles, C.L., 1994. Oedema in pigs. In: Gyles, C.L. (Ed.), Escherichia coli in Domestic Animals and Humans. Cab International, Wallingford, Oxon, U.K., pp. 193-219.

Beutin, L., Prada, S., Zimmermann, S., Stephan, R., Orskov, I., Orskov, F. 1988. Enterohemolysin, a new type of hemolysin produced by some strains of enteropathogenic E. coli (EPEC). Zentrl. Bakteriol. Mikrobiol. Hyg. A 267, 576-588.

Bielaszewska, M., Prager, R., Kock, R., Mellmann, A., Zhang, W., Tschape, H., Tarr, P.I., Karch, H., 2007. Shiga toxin gene loss and transfer in vitro and in vivo during enterohemorrhagic Escherichia coli 026 infection in humans. Appl. Environ. Microbiol. 73, 3144-3150.

Bielaszewska, M., Mellmann, A., Zhang, W., Kock, R., Fruth, A., Bauwens, A., Peters, G., Karch, H., 2011. Characterisation of the Escherichia coli strain associated with an outbreak of haemolytic uraemic syndrome in Germany 2011 a microbiological study. Lancet Infect. Dis., 70165-70167, http://dx.doi.org/10.1016/S1473-3099(11).

Björk, S., Briemer, M.E., Hansson, G.C., Karlsson, K.A., Leffler, H., 1987. Structure of blood group glycosphingolipids of human small intestine. J. Biol. Chem. 262, 6758-6765.

Bolton, D.J., 2011. Verocytotoxigenic (Shiga toxin-producing) Escherichia coli: virulence factors and pathogenicity in the farm to fork paradigm. Foodborne Pathog. Dis. 8, 357-365.

Burgess, M.N., Bywater, R.J., Cowley, C.M., Mullan, N.A., Newsome, P.M., 1978. Biological evaluation of a methanol-soluble, heat-stable Escherichia coli enterotoxin in infant mice, pigs, rabbits and calves. Infect. Immun. 21, 526-531.

China, B., Goffaux, F., 1999. Secretion of virulence factors by Escherichia coli. Vet. Res. 30, 181-202.

China, B., Goffaux, F., Pirson, V., Mainil, J., 1999. Comparison of eae, tir, $\operatorname{esp} A$, and $\operatorname{esp} B$ genes of bovine and human attaching and effacing Escherichia coli by multiplex polymerase chain reaction. FEMS Microbiol. Lett. 178, 177-182.

Clarke, S.C., Haigh, R.D., Freestone, P.P.E., Williams, P.H., 2003. Virulence of enteropathogenic Escherichia coli, a global pathogen. Clin. Microbiol. Rev. 16, 365-378.

Clavijo, A.P., Bai, J., Gomez-Duarte, O.G., 2010. The longus type IV pilus of enterotoxigenic Escherichia coli (ETEC) mediates bacterial selfaggregation and protection from antimicrobial agents. Microb. Pathog. $48,230-238$

Clements, J.D., Finkelstein, R.A., 1978. Demonstration of shared and unique immunological determinants in enterotoxins from Vibrio cholerae and Escherichia coli. Infect. Immun. 22, 709-711.

Cookson, A.L., Bennett, J., Thomson-Carter, F., Attwood, G.T., 2007. Molecular subtyping and genetic analysis of the enterohemolysin gene $(e h x A)$ from Shiga toxin-producing Escherichia coli and atypical enteropathogenic E. coli. Appl. Environ. Microbiol. 73, 6360-6369.

De Rycke, J., Milon, A., Oswald, E., 1999. Necrotoxic Escherichia coli (NTEC): two emerging categories of human and animal pathogens. Vet. Res. 30, 221-234.

Dho-Moulin, M., Fairbrother, J.M., 1999. Avian pathogenic Escherichia coli (APEC). Vet. Res. 30, 299-316

Donnenberg, M.S., Welch, R.A., 1996. Virulence determinants of uropathogenic Escherichia coli. In: Mobley, H.L.T., Warren, J.W. (Eds.), Urinary Tract Infections: Molecular Pathogenesis and Clinical Management. ASM Press, Washington, D.C., U.S.A., pp. 135-174.

Dozois, C.M., Curtiss III, R., 1999. Pathogenic diversity of Escherichia coli and the emergence of exotic islands in the gene stream. Vet. Res. 30, 157-180.

Dubreuil, J.D., 2008. Escherichia coli STb toxin and colibacillosis: knowing is half the battle. FEMS Microbiol. Lett. 278, 137-145.

Duguid, J.P., Smith, I.W., Dempster, G., Edmunds, P.N., 1955. Non flagellar filamentous appendages "Fimbriae" and haemagglutinating activity in Bacterium coli. J. Pathol. Bacteriol. 90, 335-348.

Escherich, T., 1885. Die Darmbacterien des Neugeborenen und Saglings. Fortschr. Med. 3, 515-522.

Falkow, S., 1988. Molecular Koch's postulates applied to microbial pathogenicity. Rev. Infect. Dis. 10, S274-S276.
Farfan, M.J., Inman, K.G., Nataro, J.P., 2008. The major pilin subunit of the AAF/II fimbriae from enteroaggregative Escherichia coli mediates binding to extracellular matrix proteins. Infect. Immun. 76, 4378-4384.

Flores, J., Okhuysen, P.C., 2009. Enteroaggregative Escherichia coli infection. Curr. Opin. Gastroenterol. 25, 8-11.

Fukuta, S., Magnani, J.L., Twiddy, E.M., Holmes, R.K., Ginsburg, V., 1988. Comparison of carbohydrate specificities of cholera toxin, and Escherichia coli heat-labile enterotoxins LTh-I, LT-IIa, and LT-IIb. Infect. Immun. 56, 1748-1753.

Garmendia, J., Frankel, G., Crepin, V.F., 2005. Enteropathogenic and enterohemorrhagic Escherichia coli infections: translocation, translocation, translocation. Infect. Immun. 73, 2573-2585.

Gérardin, J., Lalioui, L., Jacquemin, E., Le Bouguénec, C., Mainil, J.G., 2000. The afa-related gene cluster in necrotoxigenic and other Escherichia coli from animals belongs to the afa-8 variant. Vet. Microbiol. 76, $175-184$.

Giron, J.A., Gomez-Duarte, O.G., Jarvois, K.G., Kaper, J.B., 1997. Longus pilus of enterotoxigenic Escherichia coli and its relatedness to other type-4 pili - a minireview. Gene 192, 39-43.

Gonçalves, C., Vachon, V., Schwartz, J.L., Dubreuil, J.D., 2007. The Escherichia coli enterotoxin STb permeabilizes piglet jejunal brush border membrane vesicles. Infect. Immun. 75, 2208-2213.

Goulter, R.M., Gentle, I.R., Dykes, G.A., 2009. Issues in determining factors influencing bacterial attachment: a review using the attachment of Escherichia coli to abiotic surfaces as an example. Lett. Appl. Microbiol. 49, 1-7.

Guth, B.E., Pickett, C.L., Twiddy, E.M., Holmes, R.K., Gomes, T.A., Lima, A.A Guerrant, R.L., Francs, B.D., Trabulsi, L.R., 1986. Production of type II heat-labile enterotoxin by Escherichia coli isolated from food and human feces. Infect. Immun. 54, 529-536.

Gyles, C.L., 1994. Escherichia coli verotoxins and other cytotoxins. In: Gyles, C.L. (Ed.), Escherichia coli in Domestic Animals and Humans. Cab International, Wallingford, Oxon, U.K., pp. 365-398.

Gyles, C.L., Barnum, D.A., 1969. A heat-labile enterotoxin from strains of Escherichia coli enteropathogenic for pigs. J. Infect. Dis. 120, 419-426.

Gyles, C.L., Fairbrother, J.M., 2010. Escherichia coli. In: Gyles, C.L., Prescott, J.F., Songer, J.G., Thoen, C.O. (Eds.), Pathogenesis of Bacterial Infections in Animals. Wiley-Blackwell, Ames, IA, U.S.A., pp. 267-308.

Gyles, C.L., So, M., Falkow, S., 1974. The enterotoxin plasmids of Escherichia coli. J. Infect. Dis. 130, 40-49.

Hampson, D.J., 1994. Postweaning Escherichia coli diarrhoea in pigs. In: Gyles, C.L. (Ed.), Escherichia coli in Domestic Animals and Humans. Cab International, Wallingford, Oxon, U.K., pp. 171-191.

Harrington, S.M., Dudley, E.G., Nataro, J.P., 2006. Pathogenesis of enteroaggregative Escherichia coli infection. FEMS Microbiol. Lett. 254, 12-18.

Hartland, E.L., Batchelor, M., Delahay, R.M., Hale, C., Matthews, S., Dougan, G., Knutton, S., Connerton, I., Frankel, G., 1999. Binding of intimin from enteropathogenic Escherichia coli to Tir and to host cells. Mol. Microbiol. 32, 151-158.

Hernandes, R.T., Elias, W.P., Vieira, M.A.M., Gomes, T.A.T., 2009. An overview of atypical enteropathogenic Escherichia coli. FEMS Microbiol. Lett. 297, 137-149.

Hoey, D.E., Currie, C., Else, R.W., Nutikka, A., Lingwood, C.A., Gally, D.L., Smith, D.G., 2002. Expression of receptors for verotoxin 1 from Escherichia coli 0157 on bovine intestinal epithelium. J. Med. Microbiol. 51, 143-149.

Hoey, D.E., Sharp, L., Currie, C., Lingwood, C.A., Gally, D.L., Smith, D.G., 2003. Verotoxin 1 binding to intestinal crypt epithelial cells results in localization to lysosomes and abrogation of toxicity. Cell. Microbiol. 5, 85-97

Holmes, R.K., Twiddy, E.M., Pickett, C.L., 1986. Purification and characterization of type II heat-labile enterotoxin of Escherichia coli. Infect. Immun. 53, 464-473.

Honda, T., Tsuji, T., Takeda, Y., Miwatani, T., 1981. Immunologica non-identity of heat-labile enterotoxins from human and porcine enterotoxigenic Escherichia coli. Infect. Immun. 34, 337-340.

Huang, D.B., Mohanty, A., DuPont, H.L., Okhuysen, P.C., Chiang, T. 2006. A review of an emerging enteric pathogen: enteroaggregative Escherichia coli. J. Med. Microbiol. 55, 1303-1311.

Hurley, B.P., Jacewicz, M., Thorpe, C.M., Lincicome, L.L., King, A.J., Keusch, G.T., Acheson, D.W.K., 1999. Shiga toxins 1 and 2 translocate differently across polarized intestinal epithelial cells. Infect. Immun. 67, 6670-6677.

Jenkins, C., Perry, N.T., Cheasty, T., Shaw, D.J., Frankel, G., Dougan, G., Gunn, G.J., Smith, H.R., Paton, A.W., Paton, J.C., 2003. Distribution of the sae gene in strains of Shiga toxin-producing Escherichia coli of human and bovine origins. J. Clin. Microbiol. 41, 1775-1778.

Jensen, C.O., 1893. Ueber die Kälberruhr und deren Aetiologie. Mh. Tierhelk. 4, 97-124. 
Johannes, L., Romer, W., 2010. Shiga toxins - from cell biology to biomedical applications. Nat. Rev. Microbiol. 8, 105-116.

Johansen, M., Andresen, L.O., Jorsal, S.E., Thomsen, L.K., Waddell, T.E. Gyles, C.L., 1997. Prevention of edema disease in pigs by vaccination with verotoxin 2e toxoid. Can. J. Vet. Res. 61, 280-285.

Johnson, J.R., 1991. Virulence factors in Escherichia coli urinary tract infection. Clin. Microbiol. Rev. 4, 80-128.

Johnson, J.R., 2003. Microbial virulence determinants and the pathogenesis of urinary tract infection. Infect. Dis. Clin. North Am. 17, 261-278.

Kaper, J.B., Nataro, J.P., Mobley, H.L., 2004. Pathogenic Escherichia coli. Nat. Rev. Microbiol. 2, 123-140.

Karch, H., Meyer, T., Russmann, H., Heesemann, J., 1992. Frequent loss of Shiga-like toxin genes in clinical isolates of Escherichia coli upon subcultivation. Infect. Immun. 60, 3464-3467.

Karmali, M.A., Gannon, V., Sargeant, J.M., 2010. Verocytotoxin-producing Escherichia coli (VTEC). Vet. Microbiol. 140, 360-370.

Kauffmann, F., 1947. The serology of the coli group. J. Immunol. 57,71-100.

Kayser, H., 1903. Ueber Bakterienshämolyse, im Besonderen das Colilysin. Zeitschr. Hyg. Infektionkrankh. 42, 118-138.

Koch, R., 1884. Die Aetiologie der Tuberkulose. Mitt. Kaiser Gesundh. 2, $1-88$.

Konno, T., Yatsuyanagi, J., Saito, S., 2011. Virulence gene profiling of enteroaggregative Escherichia coli heat-stable enterotoxin 1-harbouring $E$. coli (EAST1EC) derived from sporadic diarrheal patients. FEMS Immunol. Med. Microbiol., http://dx.doi.org/10.1111/ j.1574-695X.2011.00913.x.

Konowalchuk, J., Speirs, J.I., Stavric, S., 1977. Vero response to a cytotoxin of Escherichia coli. Infect. Immun. 18, 775-779.

Lalioui, L., Jouve, M., Gounon, P., Le Bouguénec, C., 1999. Molecular cloning and characterization of the afa-7 and afa- 8 gene clusters encoding afimbrial adhesins in Escherichia coli strains associated with diarrhea or septicemia in calves. Infect. Immun. 67, 5048-5059.

Law, D., Chart, H., 1998. Enteroaggregative Escherichia coli. J. Appl. Microbiol. 84, 685-697.

Le Bouguénec, C., Bertin, Y., 1999. AFA and F17 adhesins produced by pathogenic Escherichia coli in animals. Vet. Res. 30, 317-342.

Leclerc, S., Boerlin, P., Gyles, C., Dubreuil, J.D., Mourez, M., Fairbrother, J.M., Harel, J., 2007. paa, originally identified in attaching and effacing Escherichia coli, is also associated with enterotoxigenic E. coli. Res. Microbiol. 158, 97-104.

Levine, M.M., 1987. Escherichia coli that cause diarrhea: enterotoxigenic, enteroinvasive, enterohemorrhagic and enteroadherent. J. Infect. Dis. 155, 377-389.

Lior, H., 1994. Classification of Escherichia coli. In: Gyles, C.L. (Ed.), Escherichia coli in Domestic Animals and Humans. Cab International, Wallingford, Oxon, U.K., pp. 31-72.

Ludwig, A., Goebel, W., 1997. Haemolysins of Escherichia coli. In: Sussman, M. (Ed.), Escherichia coli - Mechanisms of Virulence. Cambridge University Press, Cambridge, U.K., pp. 281-329.

Luo, Y., Frey, E.A., Pfuetzner, R.A., Creagh, A.L., Knoechel, D.G., Haynes, C.A., Finlay, B.B., Strynadka, N.C., 2000. Crystal structure of enteropathogenic Escherichia coli intimin-receptor complex. Nature 405, 1073-1077.

Mainil, J., 2002. Les souches pathogènes d'Escherichia coli chez les chiens et chats: IV) Discussion générale. Ann. Méd. Vét. 146, 219-224.

Mainil, J., 2003a. Facteurs de virulence et propriétés spécifiques des souches invasives d'Escherichia coli: I) Les adhésines et facteurs de colonisation. Ann. Méd. Vét. 147, 105-126.

Mainil, J., 2003b. Facteurs de virulence et propriétés spécifiques des souches invasives d'Escherichia coli: III) Production de toxines. Ann. Méd. Vét. 147, 327-342.

Mainil, J., 2005a. Molecular and cellular pathogenesis of bacterial infections 2) Colonisation of the mucosae: adherence factors and their interaction with host cells. Ann. Méd. Vét. (Suppl. 2), 5-14.

Mainil, J., 2005b. Molecular and cellular pathogenesis of bacterial infections 3) Development of disease: bacterial toxins and their interaction with host cells. Ann. Méd. Vét. (Suppl. 2), 15-23.

Mainil, J.G., Daube, G., 2005. Verotoxigenic Escherichia coli from animals, humans and foods: who's who? J. Appl. Microbiol. 98, 1332-1344.

Mainil, J.G., Bex, F., Dreze, P., Kaeckenbeeck, A., Couturier, M., 1992. Replicon typing of virulence plasmids of enterotoxigenic Escherichia coli isolates from cattle. Infect. Immun. 60, 3376-3380.

Mainil, J.G., Jacquemin, E., Hérault, F., Oswald, E., 1997. Presence of pap-, $s f a-$ and afa-related sequences in necrotoxigenic Escherichia coli isolates from cattle: evidence for new variants of the AFA family. Can. J. Vet. Res. 61, 193-199.

Mainil, J.G., Bez, S., Jacquemin, E., Kaeckenbeeck, A., 1998a. Les souches pathogènes d'Escherichia coli chez le chien et le chat: I) Détection des souches entérotoxinogènes (ETEC), entéropathogènes (EPEC), vérotoxinogènes (VTEC), entérohémorragiques (EHEC) et nécrotoxinogènes (NTEC). Ann. Méd. Vét. 142, 39-46.

Mainil, J.G., Daube, G., Jacquemin, E., Pohl, P., Kaeckenbeeck, A., 1998b. Virulence plasmids of enterotoxigenic Escherichia coli isolates from piglets. Vet. Microbiol. 62, 291-301.

Mainil, J.G., Jacquemin, E., Pohl, P., Fairbrother, J.M., Ansuini, A., Le Bouguénec, Ch., Ball, H.J., De Rycke, J., Oswald, E., 1999. Comparison of necrotoxigenic Escherichia coli isolates from farm animals and humans. Vet. Microbiol. 70, 123-135.

Mainil, J., Wilbaux, M., Jacquemin, E., Imberechts, H., Van Bost, S., 2001. Les souches pathogènes d'Escherichia coli chez les chiens et chats: III) Données bactériologiques et cliniques sur les souches nécrotoxinogènes et sur celles positives pour des adhésines. Ann. Méd. Vét. 145, 343-354.

Mainil, J.G., Jacquemin, E., Pohl, P., Kaeckenbeeck, A., Benz, I., 2002. DNA sequences coding for the F18 fimbriae and AIDA adhesin are localized on the same plasmid in Escherichia coli isolates from piglets. Vet. Microbiol. 86, 303-311.

Moseley, S.L., Hardy, J.W., Hucq, I., Echeverria, P., Falkow, S., 1983. Isolation and nucleotide sequence détermination of a gene encoding a heatstable enterotoxin of Escherichia coli. Infect. Immun. 39, 1167-1174.

Moxley, R.A., Smith, D.R., 2010. Attaching-effacing Escherichia coli infections in cattle. Vet. Clin. North Am. Food Anim. Pract. 26, 29-56.

Nagy, B., Fekete, P.Z., 1999. Enterotoxigenic Escherichia coli (ETEC) in farm animals. Vet. Res. 30, 259-284.

Nataro, J.P., 2005. Enteroaggregative Escherichia coli pathogenesis. Curr. Opin. Gastroenterol. 21, 4-8.

Nataro, J.P., Levine, M.M., 1994. Escherichia coli diseases in humans in Escherichia coli. In: Gyles, C.L. (Ed.), Domestic Animals and Humans. Cab International, Wallingford, Oxon, U.K., pp. 285-333.

Nataro, J.P., Kaper, J.B., 1998. Diarrheagenic Escherichia coli. Clin. Microbiol. Rev. 11, 142-201.

Nataro, J.P., Bopp, C.A., Fields, P.I., Kaper, J.B., Strockbine, N.A., 2011. Escherichia, Shigella and Salmonella. In: Versalovic, J., Caroll, K.C., Funke, G., Jorgensen, J.H., Landry, M.L., Warnock, D.W. (Eds.), Manual of Clinical Microbiology, 10th ed. ASM Press, Washington, DC, pp. 603-626.

Niewerth, U., Frey, A., Voss, T., Le Bouguénec, C., Baljer, G., Franke, S., Schmidt, M.A., 2001. The AIDA autotransporter system is associated with F18 and Stx2e in Escherichia coli isolates from pigs diagnosed with edema disease and postweaning diarrhea. Clin. Diagn. Lab. Immunol. 8, 143-149.

O’Brien, A.D., LaVeck, G.D., Thompson, M.R., Formal, S.B., 1982. Production of Shigella dysenteriae type 1-like cytotoxin by Escherichia coli. J. Infect. Dis. 146, 763-769.

Orskov, F., Orskov, I., 1992. Escherichia coli serotyping and disease in man and animals. Can. J. Microbiol. 38, 699-704.

Orskov, I., Orskov, F., 1990. Serologic classification of fimbriae. Curr. Top. Microbiol. Immunol. 151, 71-90.

Oswald, E., Schmidt, H., Morabito, S., Karch, H., Marches, O., Caprioli, A., 2000. Typing of intimin genes in human and animal enterohemorrhagic and enteropathogenic Escherichia coli: characterization of a new intimin variant. Infect. Immun. 68, 64-71.

Oxhamre, C., Richter-Dahlfors, A., 2003. Membrane-damaging toxins: family of RTX toxins. In: Burns, D.L., Barbieri, J.T., Iglewski, B.H., Rappuoli, R. (Eds.), Bacterial Protein Toxins. ASM Press, Washington D.C., U.S.A., pp. 203-214.

Pennington, H., 2010. Escherichia coli 0157. Lancet 376, 1428-1435.

Philpott, D.J., Ackerley, C.A., Kiliaan, A.J., Karmali, M.A., Perdue, M.H., Sherman, P.M., 1997. Translocation of Verotoxin-1 across T84 monolayers: mechanism of bacterial toxin penetration of epithelium. Am. J. Physiol. 273, G1349-G1358

Pickett, C.L., Twiddy, E.M., Belisie, B.W., Holmes, R.K., 1986. Cloning of genes that encode a new heat-labile enterotoxin of Escherichia coli. J. Bacteriol. 165, 348-352.

Pickett, C.L., Twiddy, E.M., Coker, C., Holmes, R.K., 1989. Cloning, nucleotide sequence, and hybridization studies of the type IIb heatlabile enterotoxin gene of Escherichia coli. J. Bacteriol. 171, 4945-4952.

Piérard, D., De Greve, H., Haesebrouck, F., Mainil, J.G., 2012. 0157:H7 and 0104:H4 Vero/Shiga toxin-producing Escherichia coli: respective role of cattle and humans. Vet. Res., http://dx.doi.org/10.1186/1297-9716-43-13.

Pruimboom-Brees, I.M., Morgan, T.W., Ackermann, M.R., Nyström, E.D., Samuel, J.E., Cornick, N.A., Moon, H.W., 2000. Cattle lack vascular receptors for Escherichia coli 0157:H7 Shiga toxins. Proc. Natl. Acad. Sci. U.S.A. 97, 10325-10329.

Radostits, O., Gay, C.C., Hinchcliff, K., Constable, P.D., 2007. Veterinary Medicine - A Textbook of the Diseases of Cattle, Horses, Sheep, Pigs, 
and Goats. Part 2: Special Medicine: Diseases Associated with Bacteria - III. Colibacillosis of Newborn Calves, Piglets, Lambs, Kids and Foals. Saunders Elsevier, Philadelphia, PA, U.S.A, pp. 851-876.

Rasheed, K., Guzman-Verduzio, L.M., Kupersztoch, Y.M., 1990. Two precursors of the heat-stable enterotoxin of Escherichia coli: evidence for extracellular processing. Mol. Microbiol. 4, 265-274.

Rasko, D.A., Rosovitz, M.J., Myers, G.S., Mongodin, E.F., Fricke, W.F., Gajer, P., Crabtree, J., Sebaihia, M., Thomson, N.R., Chaudhuri, R., Henderson, I.R., Sperandio, V., Ravel, J., 2008. The pangenome structure of Escherichia coli: comparative genomic analysis of E. coli commensal and pathogenic isolates. J. Bacteriol. 190, 6881-6893.

Saldana, Z., Sanchez, E., Xicohtencatl-Cortes, J., Puente, J.L., Giron, J.A., 2011. Surface structures involved in plant stomata and leaf colonization by Shiga-toxigenic Escherichia coli 0157:H7. Frontiers Microbiol. 2, 1-9.

Sandvig, K., Bergan, J., Dyve, A.B., Skotland, T., Torgersen, M.L., 2010. Endocytosis and retrograde transport of Shiga toxin. Toxicon 56, 1181-1185.

Savarino, S.J., Fasano, A., Watson, J., Martin, B.M., Levine, M.M., Guandalini, S., Guerry, P., 1993. Enteroaggregative Escherichia coli heat-stable enterotoxin 1 represents another subfamily of $E$. coli heat-stable toxin. Proc. Natl. Acad. Sci. U.S.A. 90, 3093-3097.

Scaletsky, I., Silva, M.L.M., Trabulsi, L.R., 1984. Distinctive patterns of adherence of enteropathogenic Escherichia coli to HeLa cells. Infect. Immun. 45, 534-536.

Scheutz, F., Moller, N.E., Frimodt-Moller, J., Boisen, N., Morabito, S., Tozzoli, R., Nataro, J., Caprioli, A., 2011. Characteristics of the enteroaggregative Shiga toxin/verotoxin-producing Escherichia coli 0104:H4 strain causing the outbreak of haemolytic uraemic syndrome in Germany May to June 2011. Euro Surveill., 16.

Scheutz, F., Teel, L.D., Beutin, L., Piérard, D., Buvens, G., Karch, H., Mellmann, A., Caprioli, A., Tozzoli, R., Morabito, S., Strockbine, N.A., Melton-Celsa, A.R., Sanchez, M., Persson, S., O'Brien, A.D., 2012. Multicenter evaluation of a sequence-based protocol for subtyping Shiga toxins and standardizing Stx nomenclature. J. Clin. Microbiol. 50, 2951-2963.

Schmidt, M.A., 2010. LEE ways: tales of EPEC ATEC and EHEC. Cell Microbiol. 12, 1544-1552.

Sears, C.L., Kaper, J.B., 1996. Enteric bacterial toxin: mechanisms of action and linkage to intestinal secretion. Microbiol. Rev. 60, 167-215.
Servin, A.L., 2005. Pathogenesis of Afa/Dr diffusely adhering Escherichia coli. Clin. Microbiol. Rev. 18, 264-292.

Sherlock, O., Schembri, M.A., Reisner, A., Klemm, P., 2004. Novel roles for the AIDA adhesin from diarrheagenic Escherichia coli: cell aggregation and biofilm formation. J. Bacteriol. 186, 8058-8065.

Smith, H.W., Halls, S., 1967. Observation by the ligated intestinal segment and oral inoculation methods on Escherichia coli infections in pigs, calves, lambs, and rabbits. J. Pathol. Bacteriol. 93, 499-529.

Sojka, W.J., 1965. Escherichia coli in Domestic Animals and Poultry. Part I General Characteristics and Biochemical Behaviour. Commonwealth Agricultural Bureaux, Farnham Royal, Bucks, U.K, pp. 1-63.

Stordeur, P., Marlier, D., Blanco, J., Oswald, E., Biet, F., Dho-Moulin, M. Mainil, J., 2002. Examination of Escherichia coli from poultry for selected adhesin genes important in disease caused by mammalian pathogenic E. coli. Vet. Microbiol. 84, 231-241.

Sussman, M., 1997. Escherichia coli and human diseases. In: Sussman, M. (Ed.), Escherichia coli - Mechanisms of Virulence. Cambridge University Press, Cambridge, U.K., pp. 3-48.

Toth, I., Schmidt, H., Dow, M., Malik, A., Oswald, E., Nagy, B., 2003. Transduction of porcine enteropathogenic Escherichia coli with a derivative of a Shiga toxin 2-encoding bacteriophage in a porcine ligated ileal loop system. Appl. Environ. Microbiol. 69, 7242-7247.

Trabulsi, L.R., Keller, R., Gomes, T.A.T., 2002. Typical and atypical enteropathogenic Escherichia coli. Emerg. Infect. Dis. 8, 508513.

Waddell, T.E., Lingwood, C.A., Gyles, C.L., 1996. Interaction of Verotoxin 2e with pig intestine. Infect. Immun. 64, 1714-1719.

Wasteson, Y., Olsvik, O., Skancke, E., Bopp, C.A., Fossum, K., 1988. Heatstable-enterotoxin-producing Escherichia coli strains isolated from dogs. J. Clin. Microbiol. 26, 2564-2566.

Weintraub, A., 2007. Enteroaggregative Escherichia coli: epidemiology, virulence and detection. J. Med. Microbiol. 56, 4-8.

World Health Organization (W.H.O.) Scientific Working Group, 1980 Escherichia coli diarrhoea. Bull. WHO 58, 23-36.

Wray, C., Woodward, M.J., 1997. Escherichia coli infections in farm animals. In: Sussman, M. (Ed.), Escherichia coli-Mechanisms of Virulence. Cambridge University Press, Cambridge, U.K., pp. 49-84.

Wu, H., Fives-Taylor, P.M., 2001. Molecular strategies for fimbrial expression and assembly. Crit. Rev. Oral Biol. Med. 12, 101-115. 